\title{
INFORMATION AND KNOWLEDGE AS ANTECEDENTS OF CONSUMER ATTITUDES AND INTENTIONS TO BUY AND RECOMMEND FAIR TRADE PRODUCTS
}

\begin{abstract}
:
The authors propose and empirically test a causal model to understand how the availability of fair trade information, and consumer knowledge about this issue, affect consumers' attitudes and intentions towards fair trade products. The model is built upon the attitude-behaviour paradigm and the premises of agency theory. It is tested through structural equation modelling with a sample of 292 Spanish consumers. The findings are that consumers do not have good knowledge about fair trade, and that this is significantly determined by the lack of information about this in the market. It is also observed that consumers' perceptions about the availability of fair trade information have negative effects on their concern about this issue, and that such information as is available is not effective in reducing consumer scepticism. The research represents an extension of previous fair trade literature because the role of information and communication in improving consumer attitudes and buying intentions has rarely been explored in the case of ethical products.
\end{abstract}

\section{Keywords:}

Fair trade; knowledge; attitudes; buying intentions; word of mouth

\section{Article classification:}

Research paper

\section{INTRODUCTION}


Consumers behave in an increasingly ethical way in their buying decisions because they have grown critical of the overindulgence and disparity of contemporary consumption (Castaldo et al., 2009). Micheletti (2003, 2) defines ethical consumption (which is also known as ethical shopping, conscious consumption or political consumption) as "actions by people who make choices among producers and products with the goal of changing objectionable institutional or market practices”. One of the most typical and successful examples of ethical consumption is fair trade, which can be described as "a trading partnership, based on dialogue, transparency and respect, which seeks greater equity in international trade. It contributes to sustainable development by offering better trading conditions to, and securing the rights of, marginalized producers and workers, especially in the South” (EFTA, 2002, 24). In essence, "fair trade means buying products from farmers in developing countries on terms that are relatively more favourable than commercial terms and marketing them in developed countries at an ethical premium” (de Pelsmacker et al., 2005a, 367). As set out by Hira and Ferrie (2006), fair trade standards include: (a) a minimum price for producers and a 'fair trade premium' to be set annually; (b) social premiums to fund development projects; (c) partial advance payments to finance small producers; (d) long-term contracts with predefined minimal prices; (e) the participation of producers in democratic cooperatives; and (f) sustainable environmental practices by producers.

As a concept in Europe, fair trade has been relatively successful, and it has grown into a global market worth $€ 2$ billion a year, with an increase of between $15 \%$ and $20 \%$ over the last decade, despite the recession (Yamoah et al., 2016). However, the market share of fair trade products remains very small compared to the market share of traditional commodities (Schollenberg, 2012). For example, there are data that show that, despite the positive attitudes of consumers and their reported willingness to pay a premium, most ethical brands and ethical-label products have an international market share of less than $1 \%$ (de Pelsmacker \& 
Janssens, 2007). Even though fair trade has adopted a more commercial orientation that is tending to converge with conventional market practices, consumption still remains low in many countries such as Spain, Italy, France and Germany, and the annual fair trade consumption per capita presents a country mean of only €5.70 in Europe (Brunner, 2014). Thus, the demand for fair trade products is much lower than the potential supply, which indicates that organizations in the fair trade market still have a long way to go in improving their marketing strategies and boosting sales volume (Obermiller et al., 2009; Schollenberg, 2012).

Researchers have traditionally argued that the inconsistencies between consumers' positive attitude towards fair trade and their buying behaviour derive from the existence of an attitude-behaviour gap in fair trade consumption (de Pelsmacker \& Janssens, 2007). Actually, the gap does not only exist for fair trade. Previous literature shows that the attitudebehaviour gap can also be seen in most pro-social consumer behaviour, including behaviour involving environmental products (Roberts, 1996) or more general corporate social responsibility issues (Boulstridge \& Carrigan, 2000). The gap means that consumers often express positive attitudes and a willingness to buy pro-social products, but do not finally make the purchase because they consider several product attributes jointly when making a buying decision, so that such things as price, quality, availability, brand knowledge, attitude and ethical attributes also have an influence (de Pelsmacker et al., 2005b).

To gain a better understanding of the reasons for the attitude-behaviour gap, scholars have paid special attention to a diverse set of explanatory concepts that characterize the contexts in which consumers form their attitudes and motivation towards fair trade consumption (Andorfer \& Liebe, 2012). Most studies explore attitudes with extended or modified versions of Ajzen's (1985) theory of planned behaviour (TPB) or within a more general attitudebehaviour paradigm. These approaches consider variables such as the consumer's positive 
and negative attitudes towards fair trade, subjective norms (i.e., the consumer's perception of social pressure from significant others in relation to the consumption of fair trade products) and perceived behavioural control (i.e., the consumer's perception of the difficulties in and obstacles to buying fair trade products). However, scholars have also shown that some of the key concepts in these models (e.g., subjective norms or behavioural control) are not relevant variables for the modelling of fair trade buying decisions (Shaw \& Shiu, 2003). At the same time, they have also argued that these approaches are open to the inclusion of additional predictors if it can be shown that these predictors capture a significant proportion of the variance in consumer intentions (Ozcaglar-Toulouse et al., 2006).

Along this line, a newer stream of research assumes that information about fair trade and consumer knowledge of fair trade issues also exert positive effects on attitudes and motivations, because they reduce the information asymmetries between producers and consumers and increase the credibility of fair trade claims (Wright \& Heaton, 2006). This idea has mostly been discussed from a marketing perspective, and studies focus primarily on identifying communication strategies that profitably satisfy consumer needs and identify consumer segments for the successful placement of fair trade products in the market (Andorfer \& Liebe, 2012). Thus, information and consumer knowledge about fair trade could be the missing links in completing the attitude-behaviour paradigm that until now has explored consumer attitudes and buying intentions in relation to fair trade products (de Pelsmacker \& Janssens, 2007). Nevertheless, the two streams of research have rarely been explored in combination with each other, and this implies that the basic theoretical foundations are still generally missing from the studies that explore information and consumer knowledge about fair trade (Andorfer \& Liebe, 2012). Andorfer and Liebe (2012) also suggest that research would greatly benefit from applying a multiple-motives perspective to understand fair trade consumption. 
On the basis of these ideas, in the present paper the authors propose and test a causal model that integrates the role of the availability of information and knowledge about fair trade in explaining consumer attitudes and intentions to buy and recommend fair trade products. The conceptual framework of the paper is based on the principles of the TPB and the agency theory (Fama, 1980), and constitutes an extension of the attitude-behaviour paradigm that defends a hierarchy of effects logic and follows a knowledge-attitudes-behaviour sequence to explain consumer intentions. In doing this, the main contribution of the paper to the literature comes from the development of a theoretical framework that extends previous models of ethical consumer behaviour, integrating two theoretical approaches that have rarely been explored in combination before. The framework is also tested empirically in a sample of Spanish consumers.

The paper is organized as follows. First, the authors provide an overview of the attitudebehaviour paradigm and the role of information and fair trade knowledge in understanding consumer intentions. In doing this, the conceptual model and the research hypotheses are presented. Second, the authors describe the research method of the study. Third, the findings are presented and discussed. Fourth, the most relevant conclusions, limitations and future lines of research that derive from the study are summarized.

\section{LITERATURE REVIEW AND DEVELOPMENT OF HYPOTHESES}

\subsection{The attitude-behaviour paradigm}

The recent overview of the state of research on individual consumption of fair trade products given by Andorfer and Liebe (2012) suggests that most studies that have explored this issue apply social psychological approaches that focus mainly on consumer attitudes. The most 
commonly accepted theoretical framework in this line of research is the TPB (Ajzen, 1985), which explores the attitude-behaviour relationships that link subjective norms, control factors, consumer attitudes, behavioural intentions and behaviour in a fixed causal sequence (Ozcaglar-Toulouse et al., 2006). According to the theory, consumers' perceptions of subjective norms and control factors lead to general attitudes that in turn lead to buying intentions and behaviour (de Pelsmacker \& Janssens, 2007). Nevertheless, Shaw and Shiu (2003) empirically concluded that behavioural control and subjective norms were not relevant variables for the modelling of fair trade buying decisions, because ethical consumers do not often refer to significant others, or lack controlling beliefs related to fair trade purchasing. Instead, attitude is presented as the strongest antecedent of consumers' buying decisions, because the greater the consumers' concern about fair trade issues, the higher their degree of interest in fair trade products, the more they like these products, and the more they want to buy them (de Pelsmacker \& Janssens, 2007). Thus, conceptual and causal models exploring fair trade consumption based on the theory of planned behaviour frequently refer only to attitudinal variables to explain consumer intentions and behaviour (de Pelsmacker \& Janssens, 2007).

Additionally, the theory of planned behaviour is primarily concerned with gaining an improved conceptual understanding of the determinants of decision making in the context of ethical consumption and, as such, it focuses on consumer intentions only and is not concerned with gaining a measure of actual behaviour (Ozcaglar-Toulouse et al., 2006). In the marketing literature, consumer intentions are frequently classified in two dimensions: buying and word-of-mouth intention (Oliver, 1999). On the one hand, the intention to continue purchasing or using the same product or service in the future is the most popular indicator of a consumer's loyalty intentions (Homburg \& Giering, 2001). On the other hand, word-ofmouth refers to informal communication directed at other consumers regarding products, 
services or companies (Westbrook, 1987). These recommendations may encourage the consumers receiving the information to show an interest in the products and start buying them. Thus, word-of-mouth represents an interesting form of consumer behaviour that organizations involved in fair trade should encourage in order to expand the fair trade market. Based on these ideas, the authors propose that:

\section{H1: Positive consumer attitudes towards fair trade positively influence buying intentions.}

H2: Positive consumer attitudes towards fair trade positively influence word-of-mouth intentions.

In addition to positive consumer attitudes, scholars have also studied negative consumer attitudes towards fair trade products, because these can also have a significant impact on consumer intentions (de Pelsmacker \& Janssens, 2007; Shaw \& Shiu, 2002). More specifically, consumer attitudes have a dual nature, reflecting 'traditional attitude' (i.e., a positive factor) and 'lack of control' (i.e., a negative factor) (Shaw \& Shiu, 2003). De Pelsmacker and Janssens (2007) define these attitudes as 'concern' and 'scepticism', respectively. Most consumers seem to have a very positive attitude towards fair trade, although there is a substantial amount of scepticism that also affects their intentions (de Pelsmacker \& Janssens, 2007). Therefore, a model of consumer intentions should always incorporate both the positive and the negative component of the overall attitude towards fair trade.

More precisely, scepticism reflects a lack of belief in the concept of fair trade, which arises because consumers consider that fair trade is too closely associated with charity and colonialism, or because they do not believe that fair trade can work in this world (de Pelsmacker \& Janssens, 2007). Scepticism is also closely related to the motivations to get involved in fair trade that are attributed by consumers to public organizations and companies 
(Lee et al., 2009). In this regard, the attribution to public organizations and companies of firm-serving and reactive motives for participating in fair trade marketing activities leads to consumers' distrust about this issue and is found to influence their reactions to products and companies unfavourably (Yoon et al., 2006). Based on these ideas, the authors propose two new research hypotheses:

\section{H3: Negative consumer attitudes towards fair trade negatively influence buying intentions.}

H4: Negative consumer attitudes towards fair trade negatively influence word-of-mouth intentions.

\subsection{Availability of information and consumer knowledge about fair trade}

Few studies in the fair trade area have drawn on the social psychological perspective of information and consumer knowledge to explain fair trade consumption (Andorfer \& Liebe, 2012). The scarce literature that there is on the topic has corroborated the view that consumers' perceptions of fair trade information have significant positive effects on consumers' intentions, especially through their effects on overall and product-specific attitudes (de Pelsmacker \& Janssens, 2007).

The role of information in fair trade consumption can be explained with arguments taken from agency theory, which deals with the study of information asymmetries in transactions where one party has more or better information than the other (Fama, 1980). The asymmetry creates an imbalance of power in the transaction, which can sometimes cause the transaction to go awry. Thus, information asymmetries cause misinformation and it is essential to overcome them in every communication process. More specifically, information asymmetries in the business context make it difficult and expensive for stakeholders (e.g., consumers) to verify what public organizations and companies (e.g., fair trade companies) are actually 
doing, and this problem can lead to a lack of trust, a bad reputation and fewer intentions to purchase (Fombrun, 2006). Examples of information asymmetries are adverse selection, moral hazard, and information monopoly (Wilson, 2008).

The primary way in which public organizations and companies combat these agency problems relies on aligning their behaviour with the interests of stakeholders and ensuring that there is transparency in corporate activities and communication (Fama, 1980). Increased information can be an effective means for avoiding the adverse selection problems identified by agency theory (Espinosa \& Trombetta, 2004), because information allows each stakeholder to supervise the resource distribution established by the company, and this can reduce the company's opportunistic use of its discretion and can induce it to offer legitimate value (de la Fuente \& de Quevedo, 2003). In this context, transparency is required for both the quantity and the quality of the information (Chauvey et al., 2015), which means that larger amounts of information about fair trade information are needed along with good quality information on monetary, quantitative and qualitative items related to fair trade issues (de Pelsmacker \& Janssens, 2007).

Additionally, fair trade products are mostly food products, and frequently fall into the category of experience goods (Caswell \& Mojduszka, 1996). For such goods, consumers cannot determine the quality of a product until they buy and use it. For experience goods, the most important issue is information and how consumers can learn about the quality of the product. What incentives do companies have to supply good quality products? What prevents companies from taking advantage of imperfect information concerning product characteristics and selling poor-quality commodities that cost less to produce than highquality commodities? There is a moral hazard for the producer who sells experience goods without a warranty to one-time consumers, because there is no penalty for selling an inferior product. In this context, information may play a role in increasing the number of consumers 
who are concerned about fair trade, by facilitating the gaining of knowledge (Caswell \& Mojduszka, 1996).

Certification networks are a good example of initiatives that promote greater information transparency in the fair trade context. Fair trade certification networks were created to document the adherence by producers and retailers to environmental and social standards (pertaining to, for example, natural resource extraction, labour conditions, or community development) (Gandenberger et al., 2011). Thus, the main objective of these certifications is to bring about more sustainable production and consumption patterns within the existing market structures (Gandenberger et al., 2011). Scholars and practitioners agree that ethical consumption can be promoted by labelling products with these certifications, because a certification label establishes transparency regarding the social and environmental conditions under which the product was produced. Thus, certification labels simplify the search for information and reduce consumers' uncertainty regarding a product's environmental and social performance. Consequently, a large number of governmental and non-governmental guidelines on sustainable consumption refer to the information given on product labels (Gandenberger et al., 2011).

Fairtrade Labelling Organizations International (FLO) is one of the most widely accepted certification networks in the world (Obermiller et al., 2009). It is a consortium of organizations that coordinate the international certification of fair trade products and provide farmers and selling companies with a generic fair trade label (owned and licensed by FLO) that is a globally recognized symbol of the international fair trade system (FLO, 2016). Products bearing this label meet the internationally agreed social, environmental and economic fair trade standards (FLO, 2016). This generic fair trade label can be found in more than one hundred and twenty countries and on a wide range of products - numbering over 
27,000 around the globe - including food and drink, cotton and clothing, and even jewellery made from fair trade gold and other precious metals (FLO, 2016).

The transparency offered by the fair trade label developed and licensed by FLO is a good example of a powerful international generic label that improves information transparency and consumer purchasing intentions. First, the label is a global and well-accepted label that is being used successfully in a wide number of countries and for a wide range of products (FLO, 2016). Second, it is expected that this label encourages consumers to perceive that by buying products with the label they are able to make a difference in the consumption patterns of their own society and internationally (Wright \& Heaton, 2006). This label identity closely matches the increasing social and ethical concerns of consumers (Shaw \& Newholm, 2002), and therefore they easily identify with it. Terry et al. (2000) suggest that brand and label attitudes formed because of a social identification process are more accessible in consumers' memories, and this greater accessibility increases the likelihood of brand/label attitude influencing the consumers' behaviour. Thus, the development of certification networks and strong fair trade brands, reinforced by good positioning and branding management, are necessary strategies to increase consumers' awareness, differentiate the brand/label from competing brands/labels and avoid the confusion and uncertainty caused in consumers by the coexistence of many rival certification networks and fair trade brands (Obermiller et al., 2009).

Nevertheless, the growth of the market for fair trade certification may be understood either as a useful attempt to raise the standards of fair trade production, or as a marketing ploy through which non-profit organizations and for-profit companies can capitalize on consumer demand for ethical products by 'fairwashing' their public images (Jaffee, 2010). Fairwashing refers to a company's involvement in the fair trade movement as part of its corporate social responsibility strategy to enhance its brand image, and/or to the selective engagement with 
fair trade by an organization with a problematic record in human rights, labour, or environmental practices, to sanitize its image and defuse activist pressure (Jaffee \& Howard, 2016). In fact, too much information about the certification schemes existing in the market may lead to consumers not being able to tell the difference between the claims made by the different labels, increasing the likelihood of a perception of fairwashing. In this regard, it is known that the average consumer may glean basic information about a product from its label ('this is good for the environment') but that details about what is being guaranteed are often lost. The ill-informed nature of consumers' demand for products with ethical labels may give organizations an incentive to adopt certification standards with few requirements, potentially creating a race-to-the-bottom dynamic (Clough, 2015). Second, consumers may become fed up with the number of different labels and their lack of transparency, and disengage from ethical consumption entirely. Even the most conscientious, committed shopper could spend hours poring over the websites of standards providers without understanding the differences between similar-sounding certification rules (Clough, 2015).

As a conclusion, and as tricky as it may seem, the authors argue that fair trade organizations and companies would significantly benefit from an enhancement of the quality of information given to stakeholders, and that this would ultimately allow stakeholders to make better forecasts and take better decisions. When stakeholders perceive that they are able to do this, it improves corporate legitimacy, which ultimately brings economic benefits for the fair trade system in terms of improved reputation and more purchases (Aerts \& Cormier, 2009). Along the same lines, de Pelsmacker and Janssens (2007) argue that the quality and quantity of information are vital factors for the credibility of ethical claims by producers and retailers, the attractiveness of ethical products, and, indirectly, the commercial success of the products and producers. Based on these ideas, the authors propose that: 
H5: The availability of information on fair trade positively influences consumer knowledge about fair trade.

H6: The availability of information on fair trade positively influences consumers' positive attitudes towards fair trade.

H7: The availability of information on fair trade negatively influences consumers' negative attitudes towards fair trade.

Finally, the authors also suggest that fair trade knowledge generated among consumers by the availability of information in the market has a direct effect on consumers' intentions concerning fair trade products. For example, in traditional models of buying behaviour, knowledge has an impact on attitudes, which in turn have impacts on behaviour (de Pelsmacker \& Janssens, 2007). Kim et al. (2010) argue that the differences they observed between consumers in different countries in terms of their consumption patterns were partly driven by the level of fair trade knowledge, which was significantly higher for the Korean than for the US consumers. In addition to this, de Pelsmacker and Janssens (2007) observe that the more people know about fair trade, the more they feel concerned about it and the less sceptical they are. Thus, in the current model the authors hypothesize that consumer knowledge has a significant and direct impact on both positive and negative attitudes towards fair trade, as the next two hypotheses suggest:

H8: Consumer knowledge about fair trade positively influences consumers' positive attitudes towards fair trade.

H9: Consumer knowledge about fair trade negatively influences consumers' negative attitudes towards fair trade.

Figure 1 shows the conceptual model that is proposed and tested in this paper.

Insert Figure 1 about here 


\section{METHOD}

\subsection{Research design}

The study focuses on examining the perceptions, attitudes and loyalty intentions of regular consumers with respect to fair trade. Consequently, the authors designed empirical research based on online surveys to be answered by respondents who were not necessarily (dedicated) fair trade or ethical buyers. More precisely, data were collected through an online survey among people closely related to a Spanish university, including students, lecturers and administrative staff members. There were two main reasons for the selection of this sample for the study.

First, in the emerging context of fair trade consumption, surveying regular consumers on the street could have negative consequences in terms of the reliability of the responses. Thus, the authors decided to minimize this risk by implementing the study in a real university research context where there are frequent awareness-raising campaigns throughout the year (e.g., permanent outlets for fair trade products, and regular lectures and film series on the fair trade concept). In this way, the authors expected to reach a higher number of consumers with a certain level of understanding of the fair trade concept, which would increase the reliability of the collected data. In this regard, the university in which the authors implemented the study is one of the eight fair trade universities in Spain. The European Commission gives this recognition only to universities that comply with the following requirements: (a) passing a fair trade policy statement; (b) selling fair trade products on campus; (c) using fair trade products at meetings; (d) organizing fair trade campaigns; and (e) setting up a fair trade steering group. In the context of this specific university, regular surveys to students, lecturers and other staff show that approximately $33 \%$ of the students, $54 \%$ of the lecturers and $54 \%$ of 
the staff members frequently buy fairtrade products for their personal consumption in their home.

Second, the authors have observed that university samples are frequent in the study of ethical and fair trade consumption patterns, as evidenced in the studies of Oumlil and Balloun (2009), Tan and Chou (2009) and Kim et al. (2010), among others.

The online link to the survey was e-mailed to everyone in the university community in March 2014. After the database had been refined and invalid surveys had been removed, the final sample was composed of 292 valid responses. The distribution of the participants in the sample was $65.4 \%$ students, $24.3 \%$ lecturers and $10.3 \%$ staff members.

\subsection{Measurement scales}

All the variables were measured with ten-point Likert-type scales (see Table 1). Specifically, availability of information was measured with a five-item scale adapted from the study of de Pelsmacker and Janssens (2007). Two items (INF1 and INF2) evaluated the quantity of information on the fair trade issue and three items (INF3 to INF5) evaluated information quality. Fair trade knowledge was measured with a three-item scale adapted from Söderlund (2002). The positive and negative attitudes of consumers towards fair trade were measured with two scales taken from the studies of Zaichkowsky (1994) and de Pelsmacker and Janssens (2007). A four-item scale evaluated the positive attitude towards fair trade (POS1 to POS4) and a new four-item scale evaluated the negative attitude of the participants (NEG1 to NEG4). Finally, buying intentions and word-of-mouth intentions were measured with two scales adapted from Zeithaml et al. (1996). A three-item scale evaluated intentions to buy fair trade products (BUY1 to BUY3), and a two-item scale evaluated intentions to recommend fair trade products to other consumers (WOM1 and WOM2).

\section{Insert Table 1 about here}




\subsection{Confirmatory and causal analyses}

The tests of the hypotheses were implemented in two stages. As a first step, the authors tested the structural validity of the conceptual model by performing a first-order confirmatory factor analysis, following the maximum robust likelihood estimation procedure in the EQS 6.1 software and including all the latent variables of the research. The purpose of this step was to confirm the goodness of fit of the model, as well as the convergent and discriminant validity between the different constructs that compose it. The authors first tested the reliability of each scale using Cronbach's alpha $(\alpha)$ and the average variance extracted (AVE) (Hair et al., 2010). Second, the convergent validity of each construct was tested by checking the value and significance of all its standardized lambdas (Steenkamp \& van Trijp, 1991). Third, the authors tested the discriminant validity among the dimensions of each construct by following the procedure of Anderson and Gerbing (1988). The authors also evaluated the goodness of fit of the analyses by exploring the Satorra-Bentler chi-square and the Comparative Fit Indices of the model - the normed fit index (NFI), the non-normed fit index (NNFI), the confirmatory fit index (CFI), the incremental fit index (IFI) and the root mean square error of approximation index (RMSEA) - (Bentler, 1992). Once the structural validity of the model had been successfully confirmed, the second step of the research consisted of testing the research hypotheses by implementing structural equation modelling using the EQS 6.1 software.

\section{FINDINGS}

The findings of the first-order confirmatory factor analysis, implemented with all the latent variables simultaneously, are presented in Table 2. Although the Satorra-Bentler chi-square was significant $(\mathrm{p}<0.05)$, this finding could be a consequence of the large size of the sample 
(over two hundred cases) (Hair et al., 2010). In contrast, all the Comparative Fit Indexes exceeded the minimum recommended value of 0.90 (NFI=0.91; NNFI=0.93; CFI $=0.95$; IFI=0.95) and the RMSEA value was lower than 0.08 (RMSEA=0.07), demonstrating a good fit of the model to the collected data. Additionally, the alphas and AVEs of all the items were above the minimum recommended values of 0.7 and 0.5 , respectively, which confirmed the internal reliability of the latent variables. The standardized lambdas of these items were also significant and greater than 0.50 , ensuring the convergent validity of the model. Finally, the authors evaluated the discriminant validity of the factorial structure, estimating the confidence intervals for the correlation between pairs of latent variables. The findings confirmed the discriminant validity of the model because no confidence interval included the value of 1 .

\section{Insert Table 2 about here}

The findings of the causal analysis are shown in Figure 2. As far as the effects of attitudes on consumer intentions are concerned, the findings support the proposed hypotheses. First, positive consumer attitudes towards fair trade improved buying $(\beta=0.68, \mathrm{t}=14.66, \mathrm{p}<0.05)$ and word-of-mouth intention $(\beta=0.75, \mathrm{t}=16.55, \mathrm{p}<0.05)$. These findings support hypotheses H1 and H2. Second, negative consumer attitudes towards fair trade negatively affected buying $(\beta=-0.12, \mathrm{t}=-1.98, \mathrm{p}<0.05)$ and word-of-mouth intention $(\beta=-0.16, \mathrm{t}=-2.81, \mathrm{p}<0.05)$. Thus, the findings also support hypotheses H3 and H4. In contrast, the findings showed that the availability of fair trade information did not have significant effects on consumers' knowledge of fair trade $(\beta=-0.07, \mathrm{t}=-0.92, \mathrm{p}>0.05)$ or on consumers' negative attitudes towards fair trade $(\beta=0.06, \mathrm{t}=0.86, \mathrm{p}>0.05)$. Additionally, the availability of information affected positive consumer attitudes towards fair trade significantly but negatively $(\beta=-0.33$, $\mathrm{t}=-5.03, \mathrm{p}<0.05)$. Thus, hypotheses H5 to H7 are not supported in this research. Nevertheless, the findings confirmed that there was a significant and positive effect of consumers' 
knowledge of fair trade on positive consumer attitudes towards fair trade $(\beta=0.37, t=6.39$, $\mathrm{p}<0.05)$, while the effect of this on negative consumer attitudes was negative $(\beta=-0.20$, $t=-$ 2.68, $\mathrm{p}<0.05)$. These findings support hypotheses H8 and H9.

\section{Insert Figure 2 about here}

\section{DISCUSSION}

The findings of this research are in line with the premises of the attitude-behaviour paradigm (Ozcaglar-Toulouse et al., 2006; de Pelsmacker \& Janssens, 2007; Shaw \& Shiu, 2003), and confirm that positive consumer attitudes influence buying and word-of-mouth intention positively, while negative attitudes affect these consumer intentions negatively. Thus, the most basic version of the causal sequence suggested by the TPB (Ajzen, 1985) is also confirmed for the consumption of fair trade products among the selected sample. Along the same lines, it is interesting to highlight that consumers in the sample show a relatively high level of concern for the fair trade issue $(\beta=7.00$, s.d.=1.98), and their scepticism towards this type of product is notably low $(\beta=4.28$, s.d. $=1.86)$. These findings lead to the interesting fact that positive attitudes have a more intense effect on consumer intentions than negative attitudes. These findings are aligned with previous findings in the academic literature. For example, Bucic et al. (2012) show that problems in the Third World are of high concern for consumers in developed countries because these individuals are not as inward-facing or as concerned with problems that directly affect their own lives and survival as consumers in developing countries (e.g., Indonesia in the paper of Bucic et al. (2012)). Spanish people do not generally have the same day-to-day worries as consumers in developing economies, and can be concerned with issues beyond their own survival, such as the problems addressed by fair trade. 
In addition to this explanation, the convenience sample used for the study may also play a part in the justification of the findings. The fact that the sample was collected on a university campus implies that the consumers selected for the study have a higher level of education than the average for the whole country, while they may also have a higher income level. These characteristics may lead them to be more ethically conscious (Quazi, 2003; Roberts, 1996) and to exhibit better attitudes towards the fair trade issue. The respondents might also be more concerned and less sceptical about fair trade because they are frequently exposed to awareness campaigns as part of the activities planned by the fair trade university to which they belong.

Nevertheless, when it comes to the exploration of the availability of information and consumers' knowledge of fair trade, the findings of the research are that consumers do not consider themselves to have a good knowledge of fair trade issues $(\beta=4.52$, s.d. $=2.17)$, and that this is significantly affected by the lack of relevant information that they perceive to exist in the market $(\beta=5.01$, s.d.=1.88). These results are aligned with previous findings in the academic literature, such as, for example, those reported by Wright and Heaton (2006). The British consumers that form Wright and Heaton's research sample, like the Spanish consumers in this sample, did not have a clear idea of what fair trade actually means. Wright and Heaton (2006) argue that the 'bite-sizing' approach to communication used by fair trade organizations and companies in the UK creates confusion and reduces both visibility and loyalty at the point of sale. More precisely, British consumers seem to be especially concerned about how much of the price goes to the producer in the developing country when they buy a fair trade product. Given the low level of fair trade consumption in many European countries, it seems that the UK situation could also be representative of other markets such as Spain, Italy, France and Germany (Castaldo et al., 2009). By contrast, the few scholars who have reported rather good fair trade knowledge among consumers are those 
who have focused on markets with a long fair trade tradition (Brunner, 2014). This is the case with the numerous studies carried out by de Pelsmacker et al. (2005a) and de Pelsmacker et al. (2005b, 2006), who have explored the perceptions and fair trade knowledge of Belgian consumers.

The findings also show that consumer perceptions concerning the availability of fair trade information have effects on consumers' positive and negative attitudes that are opposite to the theoretical effects proposed in the prior literature (Andorfer \& Liebe, 2012). The survey shows that the information currently available in the Spanish fair trade market neither has a positive effect on consumers' concern for this issue (i.e., on their positive attitudes), nor is it effective at reducing scepticism (i.e., their negative attitudes). These findings are similar to the results reported by de Pelsmacker and Janssens (2007), who observe that consumers' perceptions of the quantity of fair trade information available in the market lead to less concern about fair trade and more scepticism among the consumers in their sample. On the premises of agency theory, the authors argue that this is because fair trade information neither gives assurance of transparency nor adequately reduces the information asymmetries that exist between fair trade producers, retailers and consumers. This has a particularly negative effect on ethical credence goods, such as fair trade products, which have to demonstrate not only their quality but also their compliance with the new ethical standards of consumers (Caswell \& Mojduszka, 1996).

On the one hand, previous scholars have reported that information available in the market about fair trade is not scarce (de Pelsmacker \& Janssens, 2007). In fact, quite the opposite is true: there are huge quantities of information in the market (Wright \& Heaton, 2006). Nevertheless, there is often confusion about ethical issues in consumers' minds because there is too much wrong information and not enough high-quality information concerning ethical products (Nilsson et al., 2004). Too much information can be perceived as fairwashing 
communications and may lead to consumers becoming confused and making poorer decisions (Wansink, 2003). The numerous researchers who have explored fair trade certification and consumer perceptions (Clough, 2015; Jaffee, 2010; Jaffee \& Howard, 2016) argue that when there is a great deal of information about different fair trade labels and certification initiatives, consumers become upset, which provokes them to become disengaged from ethical consumption by reducing their concern and increasing their scepticism (Clough, 2015).

In Europe alone, there are over eight hundred ethical and fair trade brands, including commercial brands and labelling certifications, and these are neither well integrated nor promoted well (Castaldo et al., 2009; de Pelsmacker et al., 2005b). These competing brands and labelling certifications, and their complexity, may confuse consumers, undermine credibility and erode consumer confidence (Nilsson et al., 2004). In some cases, inappropriate information is communicated, which may be a factor in the failure to convince consumers that ethical purchasing decisions make a difference (de Pelsmacker \& Janssens, 2007). As reported by Wansink (2003), the value of label information hinges not only on its availability but also on its complexity and relevance to consumers. If too much information is provided to consumers, and if it is provided in a complicated format, the consumers lose the ability to utilize it, and they make poorly informed decisions because of limited time and the limitations of their short-term memory (Singh and Cole, 1993). The process of taking in the information can require an unwanted effort on behalf of the consumer (Wright \& Heaton, 2006).

Thus, it is possible to conclude that the availability of fair trade information in the Spanish market does not allow the information asymmetries to be reduced, and that this prevents improvements in consumer attitudes and intentions to buy or recommend fair trade products. Caswell and Mojduszka (1996) maintain that what consumers gain from additional 
information depends on the relative transaction costs of becoming informed. Using information imposes costs upon consumers. Thus consumers who suffer from time pressure find that the amount of information currently available in the market limits its usefulness and their ability to process it (Wright \& Heaton, 2006). Accessibility to information in an easily digestible form would therefore seem to be the key in persuading the modern consumer about the fair trade message (Hibbert \& Horne, 1996).

On the other hand, several scholars also suggest that consumers' attitudes and responses to ethical appeals are a function of their belief that they can positively influence the life and economic situation of producers in the Third World (Straughan \& Roberts, 1999). This belief is referred to as 'perceived consumer effectiveness' (Wright \& Heaton, 2006). Along these lines, Davis (1993) argues that simply claiming to be ethical is no longer enough for fair trade companies. Instead, marketers need to show how consumers choosing ethical products are helping in the struggle to preserve social equality. As Mendelson and Polonsky (1995) note, quality issues and piecemeal approaches to social and environmental concerns lead to generalized, non-specific claims in marketing communications that fail to focus consumer attention and instead require a consumer to guess the specifics of the social and environmental benefit that will be delivered. Thus, consumers would only gain from being given additional information if they are truly receptive to the fair trade message (Caswell \& Mojduszka, 1996).

\section{CONCLUSIONS, LIMITATIONS AND FUTURE LINES OF RESEARCH}

Evidence of a growing market for fair trade products exists, although the international market share of fair trade products is still small and consumers do not seem to behave fully in accordance with their ethical concerns. One of the main reasons for this discrepancy is the attitude-behaviour gap, which means that, while some consumers simply refuse to buy 
products with an unethical background, the majority of consumers make purchase decisions that are less ethical than their attitudes would suggest (de Pelsmacker et al., 2005a). A growing line of research stresses the importance of the availability of information and consumer knowledge about fair trade for closing this gap between consumer attitudes and buying behaviour (Andorfer \& Liebe, 2012). Following this line of thought, the authors of the present paper have proposed a theoretical framework, based on the principles of the TPB, the attitude-behaviour paradigm and the agency theory, to integrate the availability of fair trade information and consumer knowledge about the issue properly into a causal model that explores consumer intentions and fair trade consumption.

The findings of the study have significant implications for the management of fair trade by public organizations and selling companies. Thus the authors suggest that the first and most urgent action is to put more effort into awareness-raising campaigns, because consumer knowledge and perceptions about the availability of fair trade information are relatively poor. This is especially worrying for the promotion of fair trade because the findings of the previous literature and this paper have shown that consumer knowledge is a key antecedent of positive consumer attitudes towards fair trade, while at the same time contributing to reducing consumer scepticism about the effectiveness of this type of business practice.

Secondly, the authors suggest that public organizations and selling companies should focus their marketing and communication strategies on the benefits that consumers can bring to producers, communities and economies by purchasing fair trade products. This type of emotional information would result in better commercial outcomes and increased buying and recommendation intentions, because it has been demonstrated that consumers' positive responses to the fair trade issue are directly related to how much they think they can contribute to the welfare of producers in developing countries by buying fair trade products (Straughan \& Roberts, 1999). 
Thirdly, a better integration and promotion of the fair trade label also seems necessary, because too many fair trade brands and labels exist in the market and this can confuse consumers. The generic label licensed by the FLO is a good step forward in the coordination of the fair trade market, but further advances are still needed. The fair trade generic label has not been given enough visibility through the media, and information seems only to be distributed within minority and highly specialized circles (Wright \& Heaton, 2006). Thus its recognition is still limited among consumers, who do not seem to consider it as a significant factor that determines their buying and recommendation intentions (Castaldo et al., 2009). Finally, this study is not without its limitations, and future research should consider these in order to improve the knowledge of fair trade consumption. First, the authors used a small convenience sample that represents a limitation from the point of view of the generalizability of the findings. More precisely, the majority of participants in the sample were students and accordingly were in their twenties. Additionally, the sample was collected in a university context, where participants are expected to have better education, and even income, levels, than the average over the country. It is also significant that the study was implemented in a fair trade university where consumers might be more concerned about this issue because they are frequently exposed to awareness campaigns. The fact that the sample was exclusively collected in Spain, which is not a typical case study for the fair trade movement, also represents a limitation in terms of how the findings of the study should be interpreted and generalized to larger populations. Thus, future research would benefit from using larger samples that provide a clearer picture of consumer behaviour in different research settings. Second, attitude research has frequently been criticized for suffering from social desirability bias (Ulrich and Sarasin, 1995). In other words, it is believed that answers given by consumers about their attitudes and intentions can be misleading and unreliable, especially in situations in which they want to make a good impression on the researcher or to conform to 
social norms (de Pelsmacker et al., 2005a). In these cases, the attitudes measured tend to be more positive than actual behaviour (King \& Bruner, 2000). Thus, the authors urge future researchers to apply different methodologies (e.g., experimental designs) to control for these biases in their findings. As a third proposal for future research, once it is known how to integrate the availability of information and consumer knowledge in the attitude-behaviour paradigm, future researchers should search for more sophisticated models to understand consumer intentions and behaviour. The model in this paper is simple in nature, because the main goal was to set the theoretical framework for two specific variables and not to provide a complete model of consumer behaviour. However, future scholars could contribute to this line of research by exploring how information and knowledge interact with other affective and conative variables to explain individual fair trade consumption. Finally, the authors consider that future researchers should also pay attention to moderating factors (e.g., age or gender) that could have significant impacts on causal models of consumer behaviour concerning fair trade products.

\section{REFERENCES}

Aerts, W., \& Cormier, D. (2009). Media legitimacy and corporate environmental communication. Accounting, Organizations and Society, 34(1), 1-27.

Ajzen, I. (1985). From intention to actions: A theory of planned behavior. In J. Kuhl, \& J. Bechmand (eds.), Action Control: From Cognition to Behavior. New York, NY: Springer.

Anderson, J., \& Gerbing, D. (1988). Structural equation modelling in practice: A review and recommended two step approach. Psychology Bulleting, 103(3), 411-423.

Andorfer, V.A., \& Liebe, U. (2012). Research on fairtrade consumption. A review. Journal of Business Ethics, 106(4), 415-435. 
Bentler, P.M. (1992). On the fit of models to covariances and methodology to the bulletin. Psychology Bulletin, 112, 400-404.

Boulstridge, E., \& Carrigan, M. (2000). Do consumers really care about corporate responsibility? Highlighting the attitude-behaviour gap. Journal of Communication Management, 4(4), 355-368.

Brunner, T.A. (2014). Applying neutralization theory to fair trade buying behavior. International Journal of Consumer Studies, 38(2), 200-206.

Bucic, T., Harris, J., \& Arli, D. (2012). Ethical consumers among the millennials: A crossnational study. Journal of Business Ethics, 110(1), 113-131.

Castaldo, S., Perrini, F., Misani, N., \& Tencati, A. (2009). The missing link between corporate social responsibility and consumer trust: The case of fair trade products. Journal of Business Ethics, 84(1), 1-15.

Caswell, J.A., \& Mojduszka, E.M. (1996). Using informational labeling to influence the market for quality in food products. American Journal of Agricultural Economics, 78(5), $1248-1253$.

Chauvey, J.N., Giordano, S., Cho, C.H., \& Patten, D.M. (2015). The normativity and legitimacy of CSR disclosure: Evidence from France. Journal of Business Ethics, 130(4), 789-803.

Clough, E. (2015). The Politics of Food Labeling and Certification. In Herring, R.J. (ed.), The Handbook of Food, Politics, and Society (615-643), New York, NY: Oxford University Press.

Davis, J.J. (1993). Strategies for environmental advertising. Journal of Consumer Marketing, 10(2), 19-32. 
de la Fuente, J.M., \& de Quevedo, E. (2003). The concept and measurement of corporate reputation: An application to Spanish financial intermediaries. Corporate Reputation Review, 5(4), 280-301.

de Pelsmacker, P., \& Janssens, W. (2007). A model for fair trade buying behaviour: The role of perceived quantity and quality of information and of product-specific attitudes. Journal of Business Ethics, 75(4), 361-380.

de Pelsmacker, P., Driesen, L., \& Rayp, G. (2005a). Do consumers care about ethics? Willingness to pay for fair-trade coffee. Journal of Consumer Affairs, 39(2), 363-385.

de Pelsmacker, P., Janssens, W., Sterckx, E., \& Mielants, C. (2005b). Consumer preferences for the marketing of ethically labelled coffee. International Marketing Review, 22(5), 512530.

de Pelsmacker, P., Janssens, W., Sterckx, E., \& Mielants, C. (2006). Fair-trade beliefs, attitudes and buying behaviour of Belgian consumers. International Journal of Nonprofit and Voluntary Sector Marketing, 11(2), 125-138.

EFTA (2002). EFTA Yearbook: Challenges of Fair Trade 2001-2003. European Fair Trade Association. Mastricht, Netherlands. $\quad$ http://www.european-fairtradeassociation.org/Efta/Doc/yb01-en.pdf.

Espinosa, M., \& Trombetta, M. (2007). Disclosure interactions and the cost of equity capital: Evidence from the Spanish continuous market. Journal of Business Finance and Accounting, 34(9-10), 1371-1392.

Fama, E.F. (1980). Agency problems and the theory of the firm. Journal of Political Economy, 88, 288-307.

FLO (2016). Fairtrade Labelling Organizations International website. http://www.fairtrade.net/.

Fombrun, C.J. (2006). Corporate governance. Corporate Reputation Review, 8(4), 267-271. 
Gandenberger, C., Garrelts, H., \& Wehlau, D. (2011). Assessing the effects of certification networks on sustainable production and consumption: The cases of FLO and FSC. Journal of Consumer Policy, 34(1), 107-126.

Hair, J.F., Black, W.C., Babin, B.J., \& Anderson, R.E. (2010). Multivariate Data Analysis, 7th ed. Upper Saddle River, NJ: Pearson Prentice-Hall.

Hibbert, S., \& Horne, S. (1996). Giving to charity: Questioning the donor decision process. Journal of Consumer Marketing, 13(2), 4-13.

Hira, A., \& Ferrie, J. (2006). Fair trade: Three key challenges for reaching the mainstream. Journal of Business Ethics, 63(2), 107-118.

Homburg, C., \& Giering, A. (2001). Personal characteristics as moderators of the relationship between customer satisfaction and loyalty. An empirical analysis. Psychology and Marketing, 18(1), 43-66.

Jaffee, D. (2010). Fair trade standards, corporate participation, and social movement responses in the United States. Journal of Business Ethics, 92, 267-285.

Jaffee, D., \& Howard, P. H. (2016). Who's the fairest of them all? The fractured landscape of US fair trade certification. Agriculture and Human Values, 33(4), 813-826.

Kim, G.S., Lee, G.Y., \& Park, K. (2010). A cross-national investigation on how ethical consumers build loyalty toward fair trade brands. Journal of Business Ethics, 96(4), 589-611. King, M.F., \& Bruner, G.C. (2000). Social desirability bias: A neglected aspect of validity testing. Psychology and Marketing, 17(2), 79-103.

Lee, H., Park, T., Moon, H.K., Yang, Y., \& Kim, C. (2009). Corporate philanthropy, attitude towards corporations, and purchase intentions: A South Korea study. Journal of Business Research, 62(10), 939-946.

Llopis, R. (2007). Fair trade and global cognitive orientation: A focus on Spanish fair trade consumers. International Journal of Consumer Studies, 31(5), 468-477. 
Mendelson, N., \& Polonsky, M. (1995). Using strategic alliances to develop credible green marketing. Journal of Consumer Marketing, 12(2), 4-18.

Micheletti, M. (2003). Political Virtue and Shopping: Individuals, Consumerism, and Collective Action. New York, NY: Macmillan.

Nilsson, A., von Borgestede, C., \& Biel, A. (2004). Willingness to accept climate change strategies: The effect of values and norms. Journal of Environmental Psychology, 24, 267277.

Obermiller, C., Burke, C., Talbott, E., \& Green, G.P. (2009). 'Taste great or more fulfilling': The effect of brand reputation on consumer social responsibility advertising for fair trade coffee. Corporate Reputation Review, 12(2), 159-176.

Oliver, R.L. (1999). Whence consumer loyalty?. Journal of Marketing, 63, 33-44.

Oumlil, A.B., \& Balloun, J.L. (2009). Ethical decision-making differences between American and Moroccan managers. Journal of Business Ethics, 84(4), 457-479.

Ozcaglar-Toulouse, N., Shiu, E., \& Shaw, D. (2006). In search of fair trade: Ethical consumer decision making in France. International Journal of Consumer Studies, 30(5), 502-514.

Quazi, A.M. (2003). Identifying the determinants of corporate managers perceived social obligations. Management Decision, 41(9), 822-831.

Roberts, J.A. (1996). Will the real socially responsible consumer please step forward?. Business Horizons, 39(1), 79-83.

Schollenberg, L. (2012). Estimating the hedonic price for fair trade coffee in Sweden. British Food Journal, 114(3), 428-446.

Shaw, D., \& Newholm, T. (2002). Voluntary simplicity and the ethics of consumption. Psychology and Marketing, 17(2), 167-185.

Shaw, D., \& Shiu, E. (2002). The role of ethical obligation and self-identity in ethical consumer choice. International Journal of Consumer Studies, 26(2), 109-116. 
Shaw, D., \& Shiu, E. (2003). Ethics in consumer choice: A multivariate modeling approach. European Journal of Marketing, 37(10), 1485-1498.

Singh, S.N., \& Cole, C.A. (1993). The effects of length, content, and repetition on television commercial effectiveness. Journal of Marketing Research, 30, 91-104.

Söderlund, M. (2002). Customer familiarity and its effects on satisfaction and behavioral intentions. Psychology and Marketing, 19(10), 861-879.

Steenkamp, J., \& van Trijp, H. (1991). The use of LISREL in validating marketing constructs. International Journal of Research in Marketing, 8, 283-299.

Straughan, R., \& Roberts, J. (1999). Environmental segmentation alternatives: A look at green consumer behaviour in the new millennium. Journal of Consumer Marketing, 16(6), 558-575.

Tan, J., \& Chow, I.H. (2009). Isolating cultural and national influence on value and ethics: A test of competing hypotheses. Journal of Business Ethics, 88(1), 197-210.

Terry, D., Hogg, M., \& White, K. (2000). Attitude-Behaviour Relations: Social Identity and Group Membership. In D. Terry, \& M. Hogg (ed.), Attitudes, Behaviour and Social Context: The Role of Norms and Group Membership. Mahwah, NJ: Lawrence Erlbaum Associates. Ulrich, P., \& Sarasin, C. (1995). Facing Public Interest: The Ethical Challenge to Business Policy and Corporate Communications. London: Kluwer Academic Publications.

Wansink, B. (2003). How do front and back package labels influence beliefs about health claims?. Journal of Consumer Affairs, 37(2), 305-316.

Westbrook, R.A. (1987). Product/consumption-based affective responses and postpurchase processes. Journal of Marketing Research, 24(3), 258-270.

Wilkinson, J. (2007). Fair trade: Dynamic and dilemmas of a market oriented global social movement. Journal of Consumer Policy, 30(3), 219-239. 
Wilson, C. (2008). Adverse Selection. In S.N. Durlauf, \& L. Blume (ed.), The New Palgrave Dictionary of Economics, $2^{\text {nd }}$ edition. Basingstoke: Palgrave Macmillan.

Wright, L.T., \& Heaton, S. (2006). Fair trade marketing: An exploration through qualitative research. Journal of Strategic Marketing, 14(4), 411-426.

Yamoah, F.A., Duffy, R., Petrovici, D., \& Fearne, A. (2016). Towards a framework for understanding fairtrade purchase intention in the mainstream environment of supermarkets. Journal of Business Ethics, 136(1), 181-197.

Yoon, Y.Ç, Gürhan-Canli, Z., \& Schwarz, N. (2006). The effect of corporate social responsibility (CSR) activities on companies with bad reputations. Journal of Consumer Psychology, 16(4), 377-390.

Zaichkowsky, J. (1994). The personal involvement inventory: Reduction, revision, and application to advertising. Journal of Advertising, 23(4), 59-70.

Zeithaml, V., Berry, L., \& Parasuraman, A. (1996). The behavioural consequences of satisfaction decisions. Journal of Marketing Research, 17(4), 460-469. 
Table 1. Measurement scales

\begin{tabular}{|c|c|}
\hline Latent factors & Items \\
\hline $\begin{array}{l}\text { Availability of } \\
\text { information }\end{array}$ & $\begin{array}{l}\text { INF1) There is not a lot of information on fairtrade (r); INF2) There is not a lot of } \\
\text { information about actions of companies who sell fair trade products (r); INF3) Fair trade is } \\
\text { not a well defined concept that should be explained concisely and clearly (r); } \underline{\text { INF4) }} \text { The } \\
\text { origin of fair trade products often cannot be traced (r); } \underline{\text { INF5) }} \text { There is only low-quality } \\
\text { information about fair trade (r) }\end{array}$ \\
\hline FT knowledge & $\begin{array}{l}\text { KNW1) I have a good knowledge of the fairtrade issue; KNW2) I have a precise view of the } \\
\text { fairtrade issue; KNW3) The fairtrade issue is familiar to me }\end{array}$ \\
\hline $\begin{array}{l}\text { Positive } \\
\text { attitude }\end{array}$ & 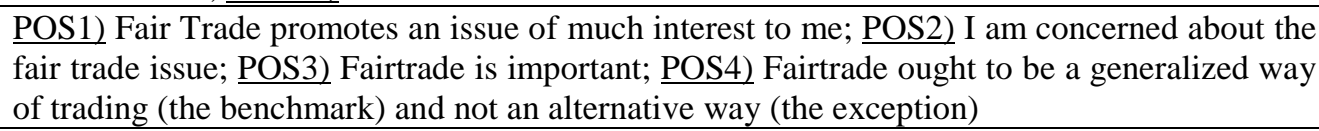 \\
\hline $\begin{array}{l}\text { Negative } \\
\text { attitude }\end{array}$ & 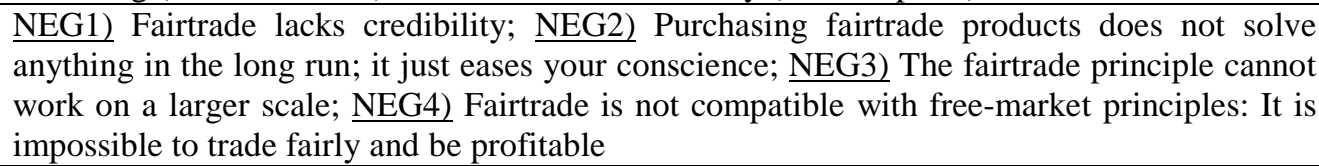 \\
\hline $\begin{array}{l}\text { Buying } \\
\text { intentions }\end{array}$ & $\begin{array}{l}\text { BUY1) I have the intention to buy fairtrade products in the future; BUY2) It is likely that I } \\
\text { will buy fairtrade products in the future; BUY3) Next time I buy a product, I will buy a } \\
\text { fairtrade product (if it is available in that category of products) }\end{array}$ \\
\hline $\begin{array}{l}\text { WOM } \\
\text { intentions }\end{array}$ & $\begin{array}{l}\text { WOM1) If someone asked me for opinion, I would recommend fairtrade products; WOM2) I } \\
\text { would recommend fairtrade products to my friends }\end{array}$ \\
\hline
\end{tabular}


Table 2. Internal consistency and convergent validity of the causal model

\begin{tabular}{|c|c|c|c|c|c|c|c|c|}
\hline \multicolumn{2}{|c|}{ Latent factors } & Mean & s.d. & Items & $\lambda^{*}$ & $\mathbf{R}^{2}$ & Cronbach $\alpha$ & AVE \\
\hline \multirow{5}{*}{\multicolumn{2}{|c|}{ Availability of information }} & \multirow{5}{*}{5.01} & \multirow{5}{*}{1.88} & INF1 & 0.92 & 0.85 & \multirow{5}{*}{0.87} & \multirow{5}{*}{0.57} \\
\hline & & & & INF2 & 0.90 & 0.80 & & \\
\hline & & & & INF3 & 0.73 & 0.53 & & \\
\hline & & & & INF4 & 0.55 & 0.30 & & \\
\hline & & & & INF5 & 0.61 & 0.37 & & \\
\hline \multirow{3}{*}{\multicolumn{2}{|c|}{ FT knowledge }} & \multirow{3}{*}{4.52} & \multirow{3}{*}{2.17} & KNW1 & 0.92 & 0.85 & \multirow{3}{*}{0.95} & \multirow{3}{*}{0.86} \\
\hline & & & & KNW2 & 0.97 & 0.95 & & \\
\hline & & & & KNW3 & 0.89 & 0.79 & & \\
\hline \multirow{4}{*}{\multicolumn{2}{|c|}{ Positive attitude }} & \multirow{4}{*}{7.00} & \multirow{4}{*}{1.98} & POS1 & 0.94 & 0.88 & \multirow{4}{*}{0.94} & \multirow{4}{*}{0.79} \\
\hline & & & & POS2 & 0.90 & 0.81 & & \\
\hline & & & & POS3 & 0.90 & 0.80 & & \\
\hline & & & & POS4 & 0.82 & 0.67 & & \\
\hline \multirow{4}{*}{\multicolumn{2}{|c|}{ Negative attitude }} & \multirow{4}{*}{4.28} & \multirow{4}{*}{1.86} & NEG1 & 0.71 & 0.51 & \multirow{4}{*}{0.82} & \multirow{4}{*}{0.53} \\
\hline & & & & NEG2 & 0.79 & 0.62 & & \\
\hline & & & & NEG3 & 0.79 & 0.62 & & \\
\hline & & & & NEG4 & 0.63 & 0.39 & & \\
\hline \multirow{3}{*}{\multicolumn{2}{|c|}{ Buying intentions }} & \multirow{3}{*}{5.80} & \multirow{3}{*}{2.29} & BUY1 & 0.97 & 0.93 & \multirow{3}{*}{0.87} & \multirow{3}{*}{0.70} \\
\hline & & & & BUY2 & 0.94 & 0.87 & & \\
\hline & & & & BUY3 & 0.82 & 0.68 & & \\
\hline \multirow{2}{*}{\multicolumn{2}{|c|}{ WOM intentions }} & \multirow{2}{*}{6.24} & & WOM1 & 0.94 & 0.89 & \multirow{2}{*}{0.94} & \multirow{2}{*}{0.88} \\
\hline & & & 2.33 & WOM2 & 0.93 & 0.87 & & \\
\hline & & & Discri & nant validity* & & & & \\
\hline & Information & $\mathbf{K n}$ & ledge & Attitude (pos) & Attit & (neg) & Buying & WOM \\
\hline Information & & $\overline{-0.0}$ & (0.07) & $-0.34(0.07)$ & & $(0.07)$ & "-0.20(0.07) & 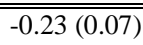 \\
\hline Knowledge & {$[(-0.19)-0.08]$} & & & $0.39(0.05)$ & & $(0.08)$ & $0.52(0.05)$ & $0.49(0.05)$ \\
\hline Attitude (pos) & {$[(-0.47)-(-0.20)]$} & & $-0.50]$ & - & & $(0.07)$ & $0.69(0.04)$ & $0.76(0.03)$ \\
\hline Attitude (neg) & {$[0.01-0.29]$} & {$[(-0.35)$} & $0.04)]$ & {$[(-0.51)-(-0.24)]$} & & & $-0.35(0.07)$ & $-0.41(0.06)$ \\
\hline Buying & {$[(-0.33)-(-0.06)]$} & & $-0.62]$ & {$[0.62-0.77]$} & {$[(-0.48)$} & $0.21)]$ & - & $0.90(0.02)$ \\
\hline WOM & {$[(-0.38)-(-0.09)]$} & & $-0.60]$ & {$[0.70-0.82]$} & {$[(-0.53$} & $0.28)]$ & [0.86-0.94] & \\
\hline
\end{tabular}

$* \mathrm{p}<0.05$; Goodness of fit: S-B $\chi^{2}(\mathrm{df})=410.62(174), \mathrm{p}=0.00$; NFI=0.91; NNFI=0.93; CFI=0.95; IFI=0.95; RMSEA=0.07

** The figures over the diagonal indicate the correlation (and error) between pairs of latent factors. The figures below the diagonal represent confidence intervals. 
Figure 1. Conceptual model

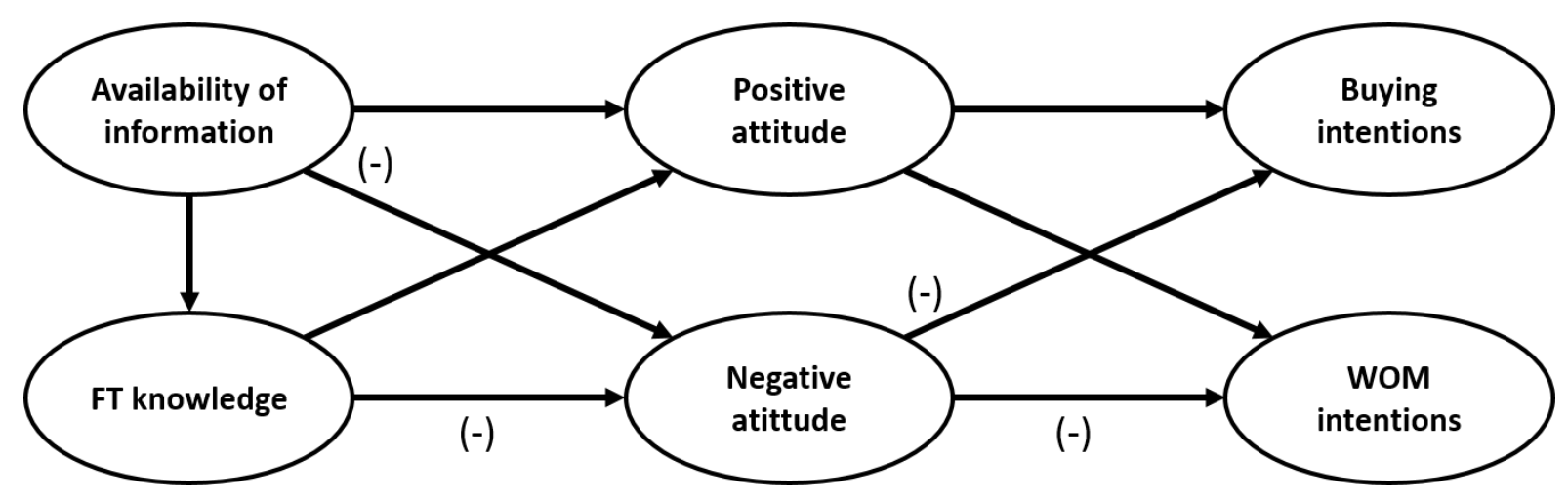


Figure 2. Findings

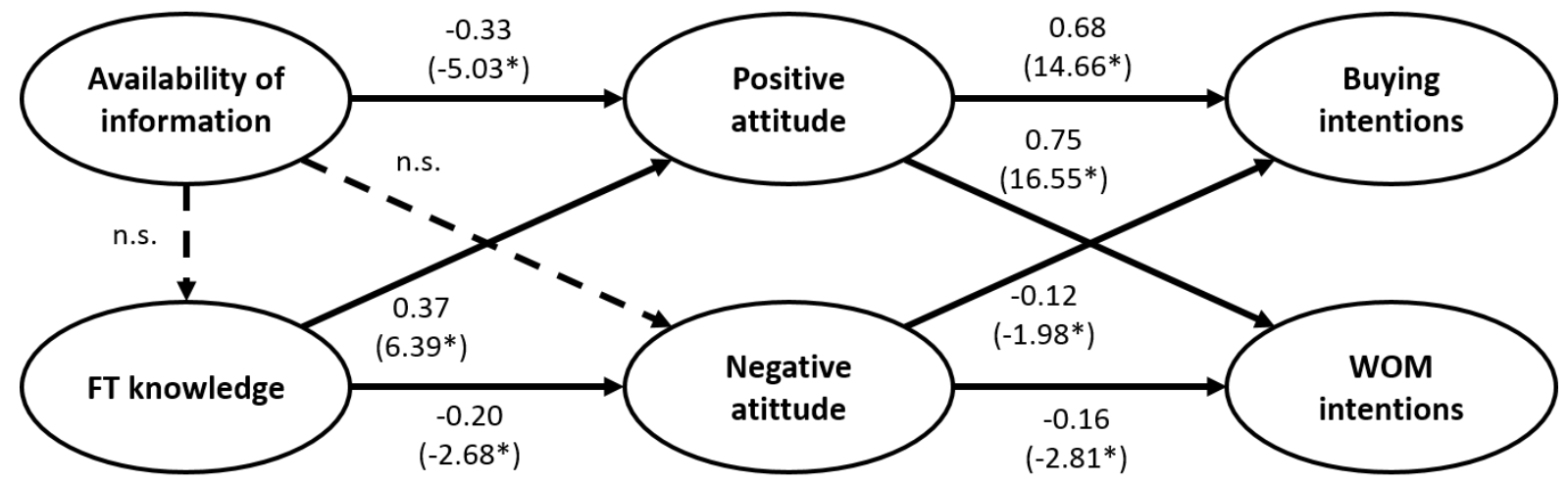

* $\mathrm{p}<0.05$; Goodness of fit: $\mathrm{S}-\mathrm{B} \chi^{2}(\mathrm{df})=343.44(175), \mathrm{p}=0.00 ; \quad \mathrm{NFI}=0.92 ; \quad \mathrm{NNFI}=0.95 ; \quad \mathrm{CFI}=0.96 ; \quad \mathrm{IFI}=0.96$; RMSEA $=0.06$ 